\title{
The Influence of Gender on the Mother- Child Interaction
}

\author{
Reetu Devi $^{*}$, Shanti Balda ${ }^{2}$, Vijay Kumar ${ }^{3}$ and Pinki Rani ${ }^{4}$ \\ ${ }^{1}$ I.C.College of Home Science CCS, HAU Hisar, Haryana, India \\ ${ }^{2}$ Department of Human Development and Family Studies, CCS, HAU, Hisar, Haryana, India \\ ${ }^{3}$ Department of Economic and Statistical Analysis, Haryana, India \\ ${ }^{4}$ FGM College, Mundi Adampur, Haryana, India \\ *Corresponding author
}

\section{A B S T R A C T}

\section{Keywords}

Temperament, Sex,

Emotions,

Responsiveness,

Encouragement and

mother-child

interaction

Article Info

Accepted:

18 August 2018

Available Online:

10 September 2018
Temperament is an individual's innate style of responding to the environment in both behavioural and emotional ways. Hisar district of Haryana state was selected for the present study. From Hisar district village Dobhi was selected purposively. 50 boys and 50 girls in the age group of 6 to 8 years were selected randomly from village Dobhi. Mothers of these children also participated in the study. Hence, the total sample for the study was 200 (50 boys and 50 girls and 100 mothers). There were two types of variables in the study i.e. independent and dependent variable. A dependent variable is a variable presumed to be affected by one or more independent variables. Motherchild Interaction was taken as dependent variable. Inventory was prepared and used. Result revealed that significant association between affection $\left(\chi 2=5.79^{*}\right)$, responsiveness $\left(\chi^{2}=10.07^{*}\right)$ and teaching $\left(\chi^{2}=11.57^{*}\right)$ domains of mother-child interaction with sex of the child.

\section{Introduction}

Children are born with their natural style of interacting with or reacting to people, places and things. This natural behaviour style in everyday situations is known as temperament. Temperament refers to our inborn personality traits, which are genetic in nature. The different ways infants interact with and react to their environment and experiences are reflective of their temperament, or behavioral style. Temperament is an individual's innate style of responding to the environment in both behavioural and emotional ways (Griggs et al.,
2009). All children have a temperament that will influence their emotions and how they adapt to change in their environments (Steinberg, 2004). In other words, the structure of adult personality is presumed to emerge from early temperament that serves as a basis for personality development (Costa and McCrae, 2000).

Thomas and Chess (1989) identified nine dimensions of temperament: activity level of child, the regularity of bodily functioning including sleep; hunger and bowel movements; adaptability to changes in routine; 
response to new situation; level of sensory threshold to produce a response to external stimulation; the general degree of distractibility; and the degree of persistence and attention span. On the basis of a profile on these dimensions, a child can be described by certain temperamental styles as easy, difficult or slow- to- warm- up. The child with an easy temperament is always cheerful, easily accepts new foods, and makes little fuss about ordinary frustration and smiles at everyone.

The child with a difficult temperament does not establish regular eating and sleeping patterns, requires a long time to new routines, is happy and unfriendly, is likely to throw tantrums at the slightest frustration. The child with slow-to-warm temperament does not take to most new offerings the first time, but given time, the child will become interested in and even enjoy, these additions to his or her life. These children are mild in their reaction and they are somewhat irregular in habits.

Some theorists have described temperament as a highly heritable construct with a strong relationship to adult personality (Bird et al., 2006). Rothbart and Bates (2006) reported that if one child is described as cheerful and upbeat, another can be described as active and energetic, and still others as calm, cautions, persistent, or prone to angry outbursts. All these behavior styles are referred to as temperament, which is early appearing, stable over time and there are individual differences in these styles.

Three main dispositional characteristics inhibition/sociability, difficult temperament and activity level have been found to influence children's interactions with others, particularly mother-child interaction. Inhibitions refer to a timid, vigilant and restrained behaviour style when faced with novel stimuli. Activity refers to the intensity and pace of a child's behaviour and speech. Difficult temperament refers to the frequent and intense expression of negative emotions (Thomas and Chess, 1989).

Temperamental characteristics indicate how children with many stresses may do well, while some with little or no stress have difficulty. While some children are mild and joyful, others are irritable. Easy children are pleasant to care for and they may receive and give back plenty of affection and attention. The fussy, energetic and difficult child may cry and kick when given attention. As development unfolds, the fussy and difficult child may create problem to the caregiver and may receive less nurturance and affection. Many parents feel guilty and feel as if they have done something to harm their child because the difficult ones are not easy to rear. Temperament may make some children in certain environments more likely to have these problems. These 'risk factors' occur when there is a mismatch between the child's temperament and demands in the environment, i.e. a poor fit between the child's temperament and expectations for behaviour in a particular situation. 'Easy' children may have 'protective' factors where mismatches are rare and the rate of conflict is low (Anonymous, 2011).

As reported by Sanson and Rothbart (2002) parents often do not become believers in temperament until after the birth of their second child. Before this time, their child's behaviour may be seen as simple and direct outcome of their upbringing. With the second child, management strategies that worked well with the first child may not be effective.

Problems experienced with the first child (in feeding, sleeping, coping with strangers) may not exist with the second, but new problems may arise. Such experiences suggest strongly that "nature" as well as "nurture" influences child development, that children differ from each other from very early in life, and that 
these differences have important implications for parent-child interaction.

Carolyn and Sheila (2009) examined child temperament and its relationship with child behavior problems and quality of mother-child interactions. Children who were perceived by their mothers as more active with a low attention span, tended to have more behavior problems and to be more non accepting or noncompliant in their interactions with their mothers. Mothers of active children, in turn, were described as more negative and nonaccepting in their responses to their children. Hence, mother-child interaction is influenced by temperament of children and vice-versa.

It is important that parents also get a clear picture of their own temperament traits. Conflicts between parents and their children may arise due to temperament clashing. When there is temperament friction between parent and child, it is more reasonable to expect that the parent should make the first move to adapt. When a parent or caregiver understands the child's temperament, he or she can organize the environment so that "goodness of fit" happens (Kathy, 2002). Mother plays an important role in transition of egocentric child to the socialized one. She is the first informal teacher of the child who prepares the child to face the strange world with confidence. The child rearing practices used by parents contribute a lot in the behaviour of the child.

Understanding temperament is important because it helps caregivers better understand children's individual differences. By understanding temperament, caregivers can learn how to help children express their preferences, desires, and feelings appropriately.

\section{Objective:}

The influence of sex on the mother- child interaction.

\section{Materials and Methods}

Hisar district of Haryana state was selected for the present study. From Hisar district village Dobhi was selected purposively. 50 boys and 50 girls in the age group of 6 to 8 years were selected randomly from village Dobhi. Mothers of these children also participated in the study. Hence, the total sample for the study was 200 (50 boys and 50 girls and 100 mothers). There were two types of variables in the study i.e. independent and dependent variable. A dependent variable is a variable presumed to be affected by one or more independent variables. Mother-child Interaction was taken as dependent variable. Inventory was prepared and used.

\section{Results and Discussion}

\section{Association between mother-child interaction and sex of child:}

$\chi^{2}$ was used to examine association between categories of different domains of motherchild interaction and sex of the child. As depicted in Table 1, there was significant association between affection $\left(\chi^{2}=5.79 *\right)$, responsiveness $\left(\chi^{2}=10.07^{*}\right)$ and teaching $\left(\chi^{2}\right.$ $=11.57 *)$ domains of mother-child interaction with sex of the child.

Results revealed that mothers were more affectionate to boys as majority of boys (78\%) fell in high category of affection domain as compared to girls (58\%). Percentage of girls was more $(32 \%)$ as compared to boys $(12 \%)$ in average category of affection. Mothers were more responsive to boys, as majority of boys fell in average category (64\%) as compared to girls $(38 \%)$. Only 12 per cent boys fell in low category of responsiveness as compared to girls $(38 \%)$. In teaching domain equal percentage $(52 \%)$ of boys and girls fell in average category. Percentage of boys was more in high category (36\%) as compared to girls $(20 \%)$, on the other hand, percentage of 
girls was greater in low category $(28 \%)$ as compared to boys (12\%). There was no association between encouragement domain and sex of the child.
It can be interpreted from these results that mothers were more affectionate and responsive for boys as compared to girls; also, mothers used more teaching strategies with boys as compared to girls.

Table.1 Association between mother-child interaction and sex of child $(n=100)$

\begin{tabular}{|c|c|c|c|c|}
\hline $\begin{array}{l}\text { Domains of mother-child } \\
\text { interaction }\end{array}$ & Categories & Boys $\left(n_{1}=50\right)$ & Girls $\left(\mathbf{n}_{2}=\mathbf{5 0}\right)$ & $\chi^{2}$ value \\
\hline \multirow[t]{3}{*}{ Affection } & Low & $05(10.0)$ & 05 (10.0) & \multirow{3}{*}{$5.79^{*}$} \\
\hline & Average & $06(12.0)$ & $16(32.0)$ & \\
\hline & High & $39(78.0)$ & $29(58.0)$ & \\
\hline \multirow[t]{3}{*}{ Responsiveness } & Low & $06(12.0)$ & $19(38.0)$ & \multirow[t]{3}{*}{$10.07 *$} \\
\hline & Average & $32(64.0)$ & $19(38.0)$ & \\
\hline & High & $12(24.0)$ & $12(24.0)$ & \\
\hline \multirow[t]{3}{*}{ Encouragement } & Low & $05(10.0)$ & $06(12.0)$ & \multirow[t]{3}{*}{1.07} \\
\hline & Average & $35(70.0)$ & $35(70.0)$ & \\
\hline & High & $10(20.0)$ & 09 (18.0) & \\
\hline \multirow[t]{3}{*}{ Teaching } & Low & $06(12.0)$ & $14(28.0)$ & \multirow[t]{3}{*}{$11.57 *$} \\
\hline & Average & $26(52.0)$ & $26(52.0)$ & \\
\hline & High & $18(36.0)$ & $10(20.0)$ & \\
\hline
\end{tabular}

Note: Figures in parentheses indicate percentages; *significant of $5 \%$ level.

Result revealed that significant association between affection $\left(\chi^{2}=5.79 *\right)$, responsiveness $\left(\chi^{2}=10.07^{*}\right)$ and teaching $\left(\chi^{2}\right.$ $\left.=11.57^{*}\right)$ domains of mother-child interaction with sex of the child. Vig and Jaswal (2008) studied mothers' perception of their sons and daughters across two levels of perceived stress and across eight dimensions of parentchild relationship. It was found that mothers who reported low stress showed significantly more accepting behaviour for their sons as compared to moderately stressed mothers.

\section{References}

Allard, L. T. and Hunter, A. 2014. Developing a strong, beneficial relationship with your child. Retrieved from <http://csefel.vanderbilt.edu/resource/ parenting-difficult-child.

Anonymous.2011.Temperament and

Parenting - Temperament.com.

Retrieved from https://www.bdi.com/temperament. comfaqs.html

Costa, P.T. and McCare, R.R. 2000. Nature over nurture : Temperament, personality and life span development. Journal of Personality and Social Psychology, 78 (1) : 173-186.

Griggs, M. S., Gagnon, S.G., Huelsman, T. J., Kidder-Ashley, P. and Ballard, M. 2009. Student-teacher relationships matter: Moderation influences between temperament and preschool social competence. Psychology in the 
Schools. 46 : 553-566.

Kashyap, I. 2013. Temperament and development domains, Unpublished Masters Thesis, HDFS, CCSHAU, Hisar.

Kathy, K. O. 2002. Understanding Your Child's Temperament. Family Life Month Packet. 5 : 1-2.

Kohnstamm, G. 1989. Temperament in Childhood: cross-cultural and sex differences. In G.A. Kohnstamm, J.E. Bates and M.K. Rothbart (Eds), Temperament in Childhood (pp.483508). New York: Wiley.

Kumari, V. 2011. Temperament, interpersonal competence and socio-metric status of 6 to 8 years old children. Ph.D. Dissertation. Department of Human Development and Family Studies, I.C. College of Home Science, CCS Haryana Agricultural University, Hisar.

Malhotra, S. and Malhotra, A. 1988. Malhotra's Temperament Schedule. National Psychogical Corporation. Agra.

Prior, M., Smart, D., Sanson, A.V. and Oberklaid, F. 1993. Sex differences in psychological adjustment from infancy to 8 years. Journal of the American Academy of Child and
Adolescence Psychiatry, 32 : 291-304. Rothbart, M. K. and Bates, J. 2006. Temperament. In W. Damon (Series Ed), \& N. Eisenberg (Vol. Ed), Handbook of child psychology: Social emotional and personality development (Vol. 3, 6th ed., pp. 99166). New York: Wiley.

Sanson, A. and Rothbart, M. K. 2002. Child temperament and parenting. In $\mathrm{M}$. Bornstein (Ed.), Applied and practical parenting (Vol. 4, pp. 299-321). Mahwah, NJ: Lawrence Erlbaum.

Steinberg, L. 2004. The 10 basic principles of good parenting. New York, NY: Simon \& Schuster Paperbacks.

Thomas, A. and Chess, S. 1989. Temperament and personality. In: GA Kohnstamm, JE Bates and MK Rothbart (Eds.): Temperament in Childhood. New York: John Wiley and Sons, pp. 249-261.

Walker, S., Berthelsen, D. and Irving, K. 2001. Temperament and peer acceptance in early childhood: Sex and social status differences. Child Study Journal, $31: 177-192$.

Vig., D. and Jaswal, J.S. 2008. Impact of Parental Stress on Their Relationship with Teenage Children. Home Comm. Sci. 2(1): 51-57.

\section{How to cite this article:}

Reetu Devi, Shanti Balda, Vijay Kumar and Pinki Rani. 2018. The Influence of Gender on the Mother- Child Interaction Int.J.Curr.Microbiol.App.Sci. 7(09): 2490-2494.

doi: https://doi.org/10.20546/ijcmas.2018.709.309 